\title{
Tolerance to neurochemical and behavioral effects of the hallucinogen 25I-NBOMe
}

\author{
Monika Herian $^{1} \cdot$ Mateusz Skawski $^{1} \cdot$ Adam Wojtas $^{1} \cdot$ Małgorzata K. Sobocińska $^{1} \cdot$ Karolina Noworyta $^{1}$. \\ Krystyna Gołembiowska' ${ }^{1}$ (i)
}

Received: 2 December 2020 / Accepted: 22 April 2021 / Published online: 25 May 2021

(c) The Author(s) 2021

\begin{abstract}
Rationale 4-Iodo-2,5-dimethoxy-N-(2-methoxybenzyl)phenethylamine (25I-NBOMe) is a potent serotonin 5-HT $2 \mathrm{~A} / 2 \mathrm{C}$ receptor agonist with hallucinogenic activity. There is no data on the 25I-NBOMe effect on brain neurotransmission and animal performance after chronic administration.

Objectives We examined the effect of a 7-day treatment with $25 \mathrm{I}-\mathrm{NBOMe}(0.3 \mathrm{mg} / \mathrm{kg} / \mathrm{day})$ on neurotransmitters' release and rats' behavior in comparison to acute dose.

Methods Changes in dopamine (DA), serotonin (5-HT), acetylcholine (ACh), and glutamate release were studied using microdialysis in freely moving rats. The hallucinogenic activity was measured in the wet dog shake (WDS) test. The animal locomotion was examined in the open field (OF) test, short-term memory in the novel object recognition (NOR) test. The anxiogenic/anxiolytic properties of the drug were tested using the light/dark box (LDB) test.

Results Repeated administration of 25I-NBOMe decreased the response to a challenge dose of DA, 5-HT, and glutamatergic neurons in the frontal cortex as well as weakened the hallucinogenic activity in comparison to acute dose. In contrast, striatal and accumbal DA and 5-HT release and accumbal but not striatal glutamate release in response to the challenge dose of 25I-NBOMe was increased in comparison to acute treatment. The ACh release was increased in all brain regions. Behavioral tests showed a motor activity reduction and memory deficiency in comparison to a single dose and induction of anxiety after the drug's chronic and acute administration.

Conclusions Our findings suggest that multiple injections of 25I-NBOMe induce tolerance to hallucinogenic activity and produce alterations in neurotransmission. 25I-NBOMe effect on short-term memory, locomotor function, and anxiety seems to be the result of complex interactions between neurotransmitter pathways.
\end{abstract}

Keywords $25 \mathrm{I}-\mathrm{NBOMe} \cdot$ Tolerance $\cdot$ Neurotransmitter release $\cdot$ Behavior

\section{Introduction}

Humans have used psychedelics (also known as serotonergic hallucinogens) for thousands of years. Nonetheless, scientists became interested in these substances only after Albert Hofmann discovered the psychoactive properties of lysergic acid diethylamide (LSD) in 1943 (Begola and Schillerstrom 2019). Although hallucinogens are derived from multiple structural families, they are known as powerful agents

Krystyna Gołembiowska

nfgolemb@cyf-kr.edu.pl

1 Department of Pharmacology, Polish Academy of Sciences, Maj Institute of Pharmacology, 12 Smętna, 31-343 Kraków, Poland producing profound changes in consciousness, perception, and mood (Halberstadt 2015). According to their chemical backbone, psychedelics can be divided into the following categories: mescaline-like phenylalkylamines, psilocybinlike tryptamines, and a small subclass of LSD-like ergolines (Fantegrossi et al. 2008). Serotonin receptors mediate their action. Phenylalkylamines display a high binding affinity mainly for not only $5-\mathrm{HT}_{2 \mathrm{~A}}$ receptors but also $5-\mathrm{HT}_{2 \mathrm{C}}$ and $5-\mathrm{HT}_{1 \mathrm{~A}}$ receptors, while tryptamines and ergolines are less selective for 5-HT receptor subtypes (Pierce and Peroutka 1989). 5- $-\mathrm{HT}_{2 \mathrm{~A}}$ receptors are primarily distributed in the cerebral cortex, especially on the apical dendrites of pyramidal cells in layer V (Weber and Andrade 2010). Several studies confirm that increased cortical release of glutamate is a common hallucinogen action mechanism (Herian et al. 
2019; Muschamp et al. 2004). By enhancing glutamate release, $5-\mathrm{HT}_{2 \mathrm{~A}}$ receptors may control cognitive processes, such as attention, executive functions, and working memory (Mirjana et al. 2004). Through activation of the cortical $5-\mathrm{HT}_{2 \mathrm{~A}}$ receptors, psychedelics evoke head twitch behavior in rodents, which corresponds to hallucinations in humans (Glennon et al. 1984). In contrast, 5- $\mathrm{HT}_{2 \mathrm{C}}$ and 5-HT $1 \mathrm{~A}$ receptors negatively contribute to the induction of head twitches (Klein et al. 2018).

Since 2010, a new class of powerful synthetic $\mathrm{N}$-(2-methoxybenzyl)-2,5-dimethoxy phenethylamine (NBOMe) hallucinogens has been present on the drug market and has been used as a legal substitute for LSD (UNODC 2016). The iodine derivative, 4-iodo-2,5-dimethoxy-N(2-methoxybenzyl)phenethylamine (25I-NBOMe), is one of the three NBOMe representatives most readily available to drug users (Lawn et al. 2014). Like other psychedelics, 25I-NBOMe acts as 5- $\mathrm{HT}_{2 \mathrm{~A}}$ and $5-\mathrm{HT}_{2 \mathrm{C}}$ receptor agonist due to its high in vitro binding affinity for these receptors ( $K_{\mathrm{i}}=0.6$ and $4.6 \mathrm{nM}$, respectively) (Rickli et al. 2015). Many studies report an inverted U-shaped dose dependence of hallucinogenic activity in rodents measured with head and body twitch counts (Elmore et al. 2018; Herian et al. 2019). Apart from head and body twitch response, 25I-NBOMe also induced back muscle contractions, a $5-\mathrm{HT}_{2 \mathrm{~A}}$-mediated behavior in rats (Elmore et al. 2018). Moreover, it caused a time-dependent and dose-dependent inhibitory effect on locomotor activity in male Swiss-Webster (Gatch et al. 2017) and C57BL/6 J mice (Halberstadt 2017). Emerging evidence suggests that hallucinogens may have therapeutic efficacy in treating specific psychiatric disorders, such as post-traumatic stress disorder, alcohol and drug addiction (Bogenschutz and Ross 2018), anxiety disorders (Grob et al. 2011), and drug-resistant depression (Carhart-Harris et al. 2017). 25I-NBOMe seems to affect dopaminergic transmission in the rat nucleus accumbens shell and medial prefrontal cortex (Miliano et al. 2019). There is scarce data on the effect of chronic administration of NBOMe on neurotransmission and behavior in animal models. However, it has been shown that after repeated administration, other hallucinogens, such as $\mathrm{LSD}$, DOM, and $25 \mathrm{CN}-\mathrm{NBOH}$, produce tolerance by downregulation of the 5- $\mathrm{HT}_{2 \mathrm{~A}}$ receptor (Buchborn et al. 2018; Buckholtz et al. 1990; Gresch et al. 2005). Furthermore, it has also been demonstrated that rewarding and reinforcing effects of 25I-NBOMe, 25B-NBOMe, and 25N-NBOMe on mice are related to the dopaminergic system, as changes in expression of dopamine $\mathrm{D}_{1}$ and $\mathrm{D}_{2}$ receptors, dopamine transporter DAT, tyrosine hydroxylase, and dopamine (DA) levels were found in the nucleus accumbens and ventral tegmental area (VTA) (Custodio et al. 2019; Jeon et al. 2019; Seo et al. 2019).

Our earlier study showed that 25I-NBOMe administered in a wide range of doses affected extracellular neurotransmitter levels in the frontal cortex and induced head twitches (Herian et al. 2019). The latter effect seemed to be related to an increased release of glutamate in response to $5-\mathrm{HT}_{2 \mathrm{~A}}$ receptor stimulation located on pyramidal cells. However, the effect of a long-term administration of 25I-NBOMe on brain neurotransmission and animal behavior has not been researched yet.

Therefore, this study aimed at determining the effect of chronic administration of 25I-NBOMe on neurotransmission in several brain regions and on behavior in comparison to acute treatment. The release of DA, serotonin (5-HT), and glutamate in the rat frontal cortex, striatum, and nucleus accumbens was studied using microdialysis in freely moving animals. Since acetylcholine (ACh) is mainly engaged in memory and learning processes, its level was also assessed in certain rat brain regions. Locomotor activity was assessed in the open field test, cognitive functions in the novel object recognition test, and anxiogenic/anxiolytic effect was examined in the light/dark box test. In addition, drug-elicited wet dog shake response was also evaluated.

\section{Material and methods}

\section{Animals}

Adult male Wistar-Han rats (280-350 g; Charles River, Germany) were used in all experiments. The animals were initially acclimatized and housed (6 per cage) in environmentally controlled rooms (ambient temperature $23 \pm 1{ }^{\circ} \mathrm{C}$, humidity $55 \pm 10 \%$, and 12:12 light:dark cycle). Rats were handled once daily before the beginning of the experiments; an enriched environment was not applied. Animals had free access to tap water and typical laboratory food (VRF 1, Special Diets Services, UK).

\section{Drugs and reagents}

4-Iodo-2,5-dimethoxy-N-(2-methoxybenzyl)phenethylamine hydrochloride (25I-NBOMe) was purchased from Chiron AS (Norway); ketamine and xylazine hydrochlorides from Biowet Puławy (Poland). All necessary chemicals of the highest purity used for analysis by high-performance liquid chromatography (HPLC) were obtained from Merck (Poland). O-phthalaldehyde (OPA) of Sigma-Aldrich (Poland) was used for the derivatization of glutamate to an electroactive compound.

\section{Drug administration}

The subcutaneous (sc) injection of 25I-NBOMe was chosen because it seems to be a suitable route of administration in the case of this compound compared to intraperitoneal injection, as shown by Halberstadt (2017). The dosage was 
chosen estimated based on our previous experiments (Herian et al. 2019), as the dose of $0.3 \mathrm{mg} / \mathrm{kg}$ was eliciting a more subtle yet profound effect in comparison to higher doses, which seemed favorable for chronic administration. Moreover, the NBOMes are connected with increased toxicity in humans (Halberstadt 2017); therefore, the dose of $0.3 \mathrm{mg} /$ $\mathrm{kg}$ was chosen to prevent the possible toxic effects in rats. To ensure the development of possible tolerance, the 7-day dosing regimen of consecutive injections was selected.

One group of animals received once-daily sc injections of $25 \mathrm{I}-\mathrm{NBOMe}$ at a dose of $0.3 \mathrm{mg} / \mathrm{kg} / \mathrm{day}$ for 7 days. 25I-NBOMe was dissolved in $0.9 \% \mathrm{NaCl}$. The second group received $0.9 \% \mathrm{NaCl}$ solution in the same manner. The next day, both experimental groups were administered a $0.3 \mathrm{mg} / \mathrm{kg}$ dose of 25I-NBOMe. The behavioral tests were conducted $20 \mathrm{~min}$ after the injection. Another cohort of rats was treated with $25 \mathrm{I}-\mathrm{NBOMe}$ at a dose of $0.3 \mathrm{mg} / \mathrm{kg} /$ day or $0.9 \% \mathrm{NaCl}$ solution for 7 days. Animals were implanted with microdialysis probes. The next day, microdialysis experiments were performed. Schematic presentation of drug treatments is presented in Scheme 1.

\section{Brain microdialysis}

A total of $75 \mathrm{mg} / \mathrm{kg}$ and $10 \mathrm{mg} / \mathrm{kg}$ of ketamine and xylazine, respectively, were injected intramuscularly to anesthetize animals. Microdialysis probes (MAB 4.15.3Cu, MAB 4.15.4Cu, AgnTho's AB, Sweden) were implanted into the following brain structures using the determined coordinates $(\mathrm{mm})$ : frontal cortex $\mathrm{AP}+2.7, \mathrm{~L}+0.8, \mathrm{~V}-6.5$, striatum $\mathrm{AP}+1.2, \mathrm{~L}+2.8, \mathrm{~V}-7.0$, and nucleus accumbens $\mathrm{AP}+1.6$, $\mathrm{L}+1.0, \mathrm{~V}-8.0$; from the dura (Paxinos and Watson 1998). The implantation of microdialysis probes in rats receiving multiple injections was performed after the last injection. The following day, probe inlets were connected to a syringe pump (BAS, West Lafayette, IN, USA) which delivered artificial cerebrospinal fluid composed of the following (mM): 147 $\mathrm{NaCl}, 4 \mathrm{KCl}, 2.2 \mathrm{CaCl}_{2} \cdot 2 \mathrm{H}_{2} \mathrm{O}$, and $1.0 \mathrm{MgCl}_{2}$ at a flow rate of $2 \mu \mathrm{L} / \mathrm{min}$. Five baseline samples were collected every $20 \mathrm{~min}$ after the washout period of $2 \mathrm{~h}$. A challenge dose $(0.3 \mathrm{mg} /$ $\mathrm{kg}$ ) of 25I-NBOMe was administered, and dialysate fractions were collected for the next $240 \mathrm{~min}$. As the experiment ended, the rats were terminated and their brains underwent histological examination to validate the probe placement.

\section{Extracellular concentration of DA, 5-HT, ACh, and glutamate}

Extracellular DA and 5-HT levels were analyzed by HPLC with electrochemical detection. Chromatography was performed using an Ultimate 3000 System (Dionex, USA), electrochemical detector Coulochem III (model 5300; ESA, USA) with a 5020 guard cell, a 5040 amperometric cell, and a Hypersil Gold C18 analytical column $(3 \mu \mathrm{m}$, $100 \times 3 \mathrm{~mm}$; Thermo Fisher Scientific, USA). The mobile
Scheme 1 Schematic presentation of drug treatments

\section{BEHAVIORAL TESTING}
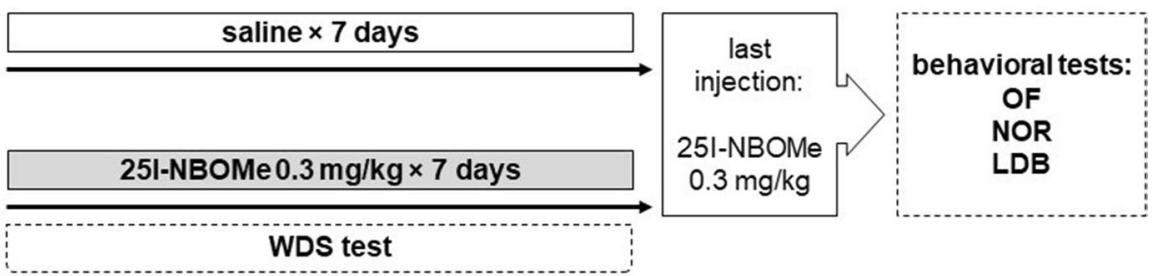

NEUROCHEMICAL RESPONSE

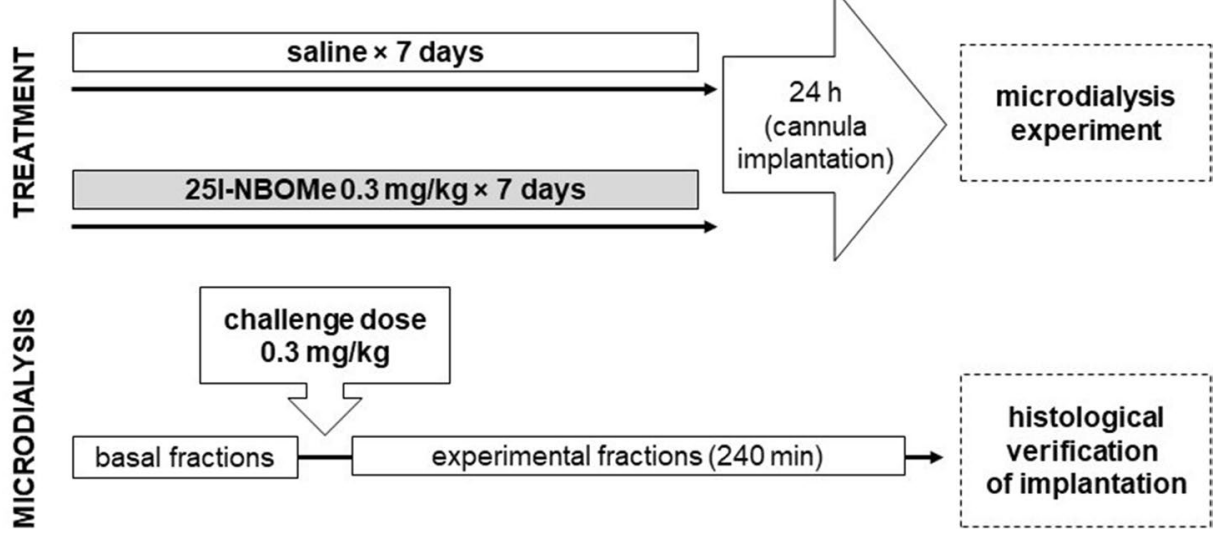


phase consisted of $0.1 \mathrm{M} \mathrm{KH}_{2} \mathrm{PO}_{4}$ buffer at $\mathrm{pH} 3.8,0.5 \mathrm{mM}$ $\mathrm{Na}_{2}$ EDTA, $100 \mathrm{mg} / \mathrm{L}$ 1-octanesulfonic acid sodium salt, and $2 \%$ methanol. The flow rate during analysis was set at $0.6 \mathrm{~mL} / \mathrm{min}$, and the applied potential of a guard cell was $600 \mathrm{mV}$, whereas the amperometric cell was $300 \mathrm{mV}$ with a sensitivity set at $10 \mathrm{nA} / \mathrm{V}$. The chromatographic data were processed by Chromeleon v.6.80 (Dionex) software package. The detection limit in dialysates was $0.002 \mathrm{pg} / 10 \mu \mathrm{L}$ for DA and $0.01 \mathrm{pg} / 10 \mu \mathrm{L}$ for 5 -HT.

Extracellular levels of ACh were analyzed by UHPLC with electrochemical detection. The ACh analysis is based on ionpairing HPLC separation, followed by on-line enzymatic conversion of ACh to hydrogen peroxide and detection on a Pt working electrode (SenCell with $2 \mathrm{~mm} \mathrm{Pt}$ working electrode) and HyREF reference electrode at the potential of $200 \mathrm{mV}$. Chromatography was performed using the ALEXYS Neurotransmitter Analyzer, a DECADE Elite electrochemical detector, AS 110 Autosampler, and LC 110 pump (Antec Leyden B. V., Zoeterwoude, The Netherlands). ACh as positively charged was separated on Acquity UPLC HSS T3 analytical column $(1.8 \mu \mathrm{m}, 1 \times 50 \mathrm{~mm}$; Waters, Milford, MA, USA). After separation, ACh passed through an immobilized enzyme reactor AChE/ChOx IMER (AC-ENZYM II, $1 \times 4$ mm, Eicom, Kyoto, Japan). The mobile phase was composed of $50 \mathrm{mM}$ monosodium orthophosphate buffer adjusted to $\mathrm{pH}$ 7.8, $0.5 \mathrm{mM} \mathrm{Na}_{2} \mathrm{EDTA}, 2.8 \mathrm{~g} / \mathrm{L}$ 1-octanesulfonic acid sodium salt, and $0.5 \mathrm{mM}$ tetramethylammonium chloride. The flow rate during analysis was set to $0.05 \mathrm{~mL} / \mathrm{min}$. The chromatographic data were processed by the CLARITY v.6.2.0.208 (DataApex Ltd.) chromatography software run on a personal computer. The detection limit of ACh in dialysates was $1.1 \mathrm{nM}$.

Glutamate levels in the extracellular fluid were measured electrochemically after derivatization with OPA/sulfite reagent to form isoindole-sulfonate derivative (Rowley et al. 1995). Chromatography was performed using an Ultimate 3000 pump (Dionex), LC-4B amperometric detector with a cross-flow detector cell (BAS), and an HR-80 column $(3 \mu \mathrm{m}, 80 \times 4.6 \mathrm{~mm}$; ESA, USA). The mobile phase was composed of $100 \mathrm{mM}$ monosodium orthophosphate at $\mathrm{pH} 4.6$ and $4 \%$ methanol. The flow rate during analysis was set to $1 \mathrm{~mL} / \mathrm{min}$ and the applied potential of a 3-mm glassy carbon electrode was set at $+600 \mathrm{mV}$ at a sensitivity of $5 \mathrm{nA} / \mathrm{V}$. The glutamate-derivative peak was compared with the respective standard, and the data were processed using the Chromax 2005 (Pol-Lab, Poland) software. The detection limit of glutamate in dialysates was $0.03 \mathrm{ng} / 10 \mu \mathrm{L}$.

\section{Wet dog shake test}

The rats' behavior, defined as rapid shaking of the head, neck, and trunk from one side to the other, resembling a wet dog shaking to dry itself, is called as wet dog shake (WDS). The WDS test was carried out based on the procedure reported by Nagayama and Lu (1996). Measurements of WDS were conducted for $80 \mathrm{~min}$ after each injection and were expressed as an average of sum values of all episodes during the observation time.

\section{Open field test}

The open field (OF) test was based on the procedure described by Rogoz and Skuza (2011). The laboratory room was dark, and only the center of the open field was illuminated with a bright light $(150 \mathrm{~lx})$ above the platform. Rats were placed in the middle of the black round arena $(1 \mathrm{~m}$ in diameter, divided into 8 sections). During a 10-min test, rats' exploratory activity, expressed as the time of walking, a number of sector line crossings, and the episodes of peeping under the edge of the arena, was measured.

\section{Novel object recognition test}

The procedure of the novel object recognition (NOR) test was performed according to Antunes and Biala (2012) and Orzelska-Gorka et al. (2016). An apparatus consisted of a wooden box with black-painted walls $(60 \times 60 \times 40 \mathrm{~cm})$ and a bright light (150 lx) focused on the center. Animals were left to acclimate to the new environment $24 \mathrm{~h}$ before the testing. On the day of the experiment, rats were habituated to a dimly lit experimental room for at least $1 \mathrm{~h}$ before the procedure. The NOR test consisted of an introductory and recognition session (5 min each) with a 30-min inter-session interval. The introductory session was performed with two identical objects (A1 and A2) situated in opposite corners. During the recognition session, one object was replaced with a novel one ( $\mathrm{A}=$ familiar, $\mathrm{B}=$ novel). The location of a novel object in the recognition session was randomly assigned to each rat. The novel objects were used interchangeably in each experimental group. The object exploration was defined as sniffing or touching with one's nose and/or forepaws. The exploration time was measured using a digital laboratory timer. The arena and the objects were cleaned between each session. Recognition index (Ri) was calculated as the time of exploration of a novel object relative to the total exploration time of both objects. The " $R$ " " ratio over $50 \%$ was defined as successful discrimination.

\section{Light/dark box test}

The light/dark box (LDB) test was performed using four computer-controlled Seamless Open Field Arenas for rats $(43 \times 43 \times 30 \mathrm{~cm}$; Med Associates, USA $)$ with 16 infrared emitters and photodetectors on each side of the box. The procedure of Noworyta-Sokolowska et al. (2019) was adapted to the experimental design. A dark insert with a hole divided the chamber into two equally sized compartments: a light compartment and a dark one. An additional light source $(220 \mathrm{~lm})$ was placed above the light compartment to make it more 
anxiogenic. Animals were placed in the dark compartment and were allowed to explore the arena freely for $15 \mathrm{~min}$. The measured parameters included ambulatory distance, vertical and stereotypic activity time, and the time spent in the dark and light compartment. The data were collected using the Med State software (activity monitor, Med Associates).

\section{Data analysis}

Drug effects on DA, 5-HT, ACh, and glutamate release in the brain regions were analyzed with repeated measures ANOVA or one-way ANOVA, where appropriate, on normalized responses followed by Tukey's post hoc test. All obtained data were presented as a percent of the basal level assumed to be $100 \%$. The WDS test, locomotor behavior of rats in the OF test, and cognitive functions in the NOR test were analyzed using one-way ANOVA followed by Tukey's post hoc test. The data collected from the LDB test were analyzed using Mann-Whitney $U$ test or Wilcoxon $T$ test. The differences were considered significant if $p<0.05$. The detected outliers were removed from the data set using Grubb's test. All statistical analyses were carried out using STATISTICA v.10 StatSoft Inc. 1984-2011 (USA) and GraphPad Prism v.5.00 GraphPad Software Inc. (USA).

\section{Results}

\section{The effect of acute and chronic administration of 25I-NBOMe on the extracellular levels of DA, 5-HT, $A C h$, and glutamate in the rat frontal cortex}

25I-NBOMe significantly increased extracellular levels of DA, 5-HT, and glutamate in the rat frontal cortex (Fig. 1a, b, c). However, the response of DA, 5-HT, and glutamate systems to a challenge dose of $0.3 \mathrm{mg} / \mathrm{kg}$ in animals treated repeatedly for 7 days with 25I-NBOMe was weaker in comparison to acutely injected rats. Repeated measures ANOVA showed an effect of treatment $\left(F_{2,15}=457, p<0.0001\right)$ and time $\left(F_{11,165}=7.1, p<0.0001\right)$ on DA levels, and a time $\times$ treatment interaction $\left(F_{22,165}=8.3, p<0.0001\right)$. There was an effect of treatment $\left(F_{2,15}=600, p<0.0001\right)$ and time $\left(F_{11,165}=29, p<0.0001\right)$ on 5-HT levels, and a time $\times$ treatment interaction $\left(F_{22,165}=14, p<0.0001\right)$. Similarly, there was an effect of treatment $\left(F_{2,15}=119, p<0.0001\right)$ and time $\left(F_{11,165}=13, p<0.0001\right)$ on glutamate levels, and a time $\times$ treatment interaction $\left(F_{22,165}=7.9, p<0.0001\right)$. In contrast, extracellular ACh levels increased in response to a challenge dose of $0.3 \mathrm{mg} / \mathrm{kg}$ in animals treated repeatedly for 7 days with 25I-NBOMe in comparison to control and

\section{FRONTAL CORTEX}
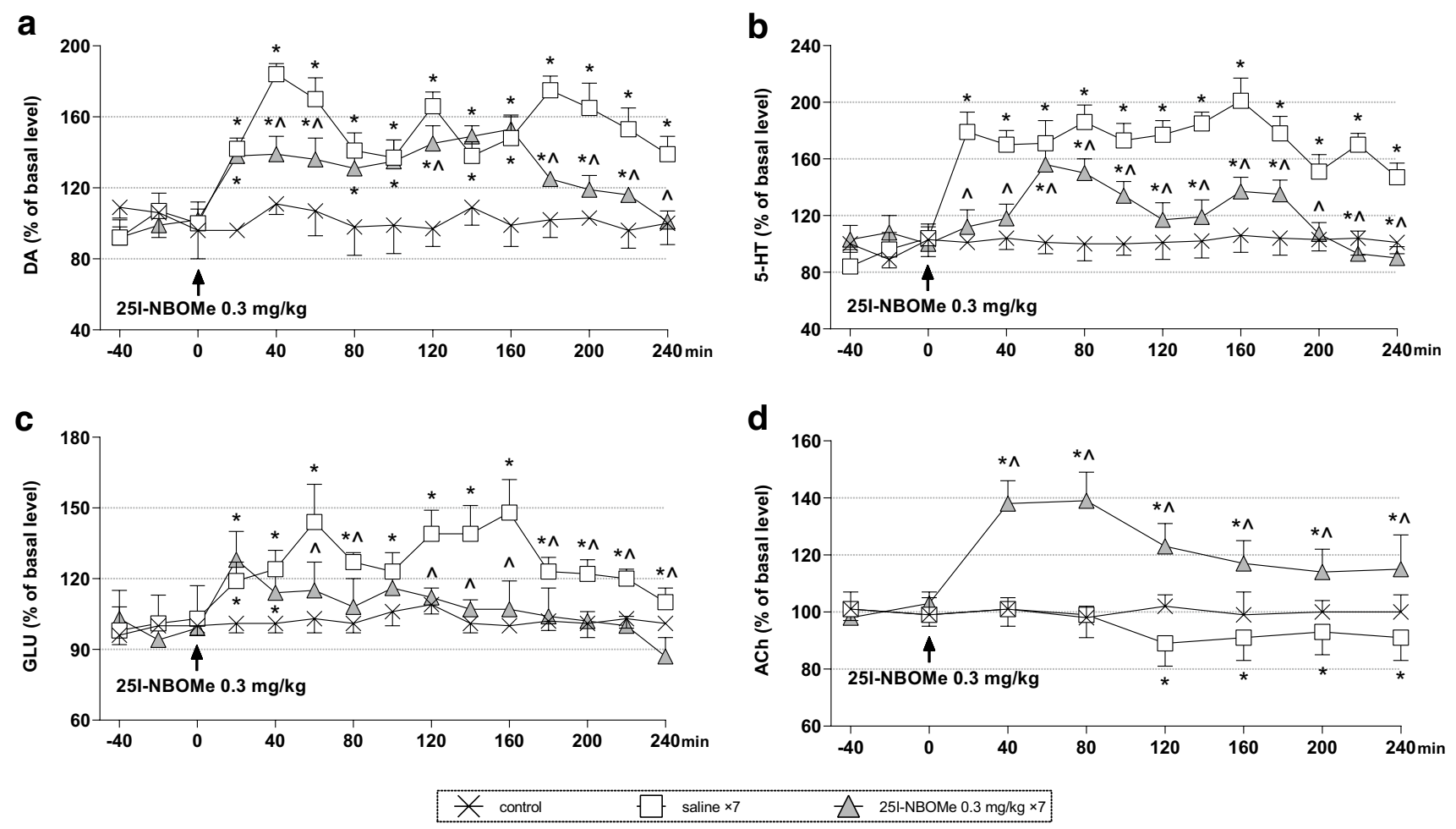

Fig. 1 The time-course effect of 25I-NBOMe on extracellular levels of dopamine (DA), serotonin (5-HT), glutamate (GLU), and acetylcholine $(\mathrm{ACh})$ in the rat frontal cortex (a-d), respectively. Values are the mean \pm standard error of the mean (SEM), $n=6$ per experimental group. The drug injection is indicated with an arrow. $* p<0.01$ vs. control group; $\wedge p<0.01$ saline vs. repeated 25I-NBOMe administration (repeated measures ANOVA and Tukey's post hoc test) 
acutely treated group (Fig. 1d). Repeated measures ANOVA showed an effect of treatment $\left(F_{2,15}=1254, p<0.0001\right)$ and time $\left(F_{5,75}=16, p<0.0001\right)$ on ACh levels, and a time $\times$ treatment interaction $\left(F_{10,75}=6.8, p<0.0001\right)$.

\section{The effect of acute and chronic administration of 25I-NBOMe on the extracellular levels of DA, 5-HT, $\mathrm{ACh}$, and glutamate in the rat striatum}

The enhancement in DA and 5-HT extracellular levels in response to a challenge dose of $0.3 \mathrm{mg} / \mathrm{kg}$ was stronger in animals treated repeatedly with 25I-NBOMe than in acutely injected rats (Fig. 2a, b). In contrast, the glutamatergic response to the challenge dose decreased in animals receiving repeated doses of 25I-NBOMe in comparison to acutely injected rats (Fig. 2c). Repeated measures ANOVA showed an effect of treatment $\left(F_{2,15}=251, p<0.0001\right)$ and time $\left(F_{11,165}=33, p<0.0001\right)$ on DA levels, and a time $\times$ treatment interaction $\left(F_{22,165}=20, p<0.0001\right)$. There was an effect of treatment $\left(F_{2,15}=1136, p<0.0001\right)$ and time $\left(F_{11,165}=25, p<0.0001\right)$ on 5-HT levels, and a time $\times$ treatment interaction $\left(F_{22,165}=12, p<0.0001\right)$. Similarly, there was an effect of treatment $\left(F_{2,15}=256, p<0.0001\right)$, and time $\left(F_{11,165}=19, p<0.0001\right)$ on glutamate levels, and a time $\times$ treatment interaction $\left(F_{22,165}=37, p<0.0001\right)$. The response of ACh neurons to a challenge dose of $0.3 \mathrm{mg} /$ $\mathrm{kg}$ increased in animals treated repeatedly for 7 days with 25I-NBOMe in comparison to control and acutely injected group (Fig. 2d). Repeated measures ANOVA showed an effect of treatment $\left(F_{2,15}=447, p<0.0001\right)$ and time $\left(F_{5,75}=10, p<0.0001\right)$ on ACh levels, and a time $\times$ treatment interaction $\left(F_{10,75}=25, p<0.0001\right)$.

\section{The effect of acute and chronic administration of 25I-NBOMe on the extracellular levels of DA, 5-HT, $A C h$, and glutamate in the rat nucleus accumbens}

The response of DA, 5-HT, and glutamate neurons to a challenge dose of $0.3 \mathrm{mg} / \mathrm{kg}$ in animals treated repeatedly with 25I-NBOMe was more potent than in acutely injected rats (Fig. 3a, b, c). Repeated measures ANOVA showed an effect of treatment $\left(F_{2,15}=1173, p<0.0001\right)$ and time $\left(F_{11,165}=86\right.$, $p<0.0001)$ on DA levels, and a time $\times$ treatment interaction $\left(F_{22,165}=47, p<0.0001\right)$. There was also an effect of treatment $\left(F_{2,15}=952, p<0.0001\right)$ and time $\left(F_{11,165}=57\right.$, $p<0.0001)$ on 5 -HT levels, and a time $\times$ treatment interaction $\left(F_{22,165}=27, p<0.0001\right)$. The treatment effect on glutamate levels was significant $\left(F_{2,15}=705, p<0.0001\right)$, and

\section{STRIATUM}
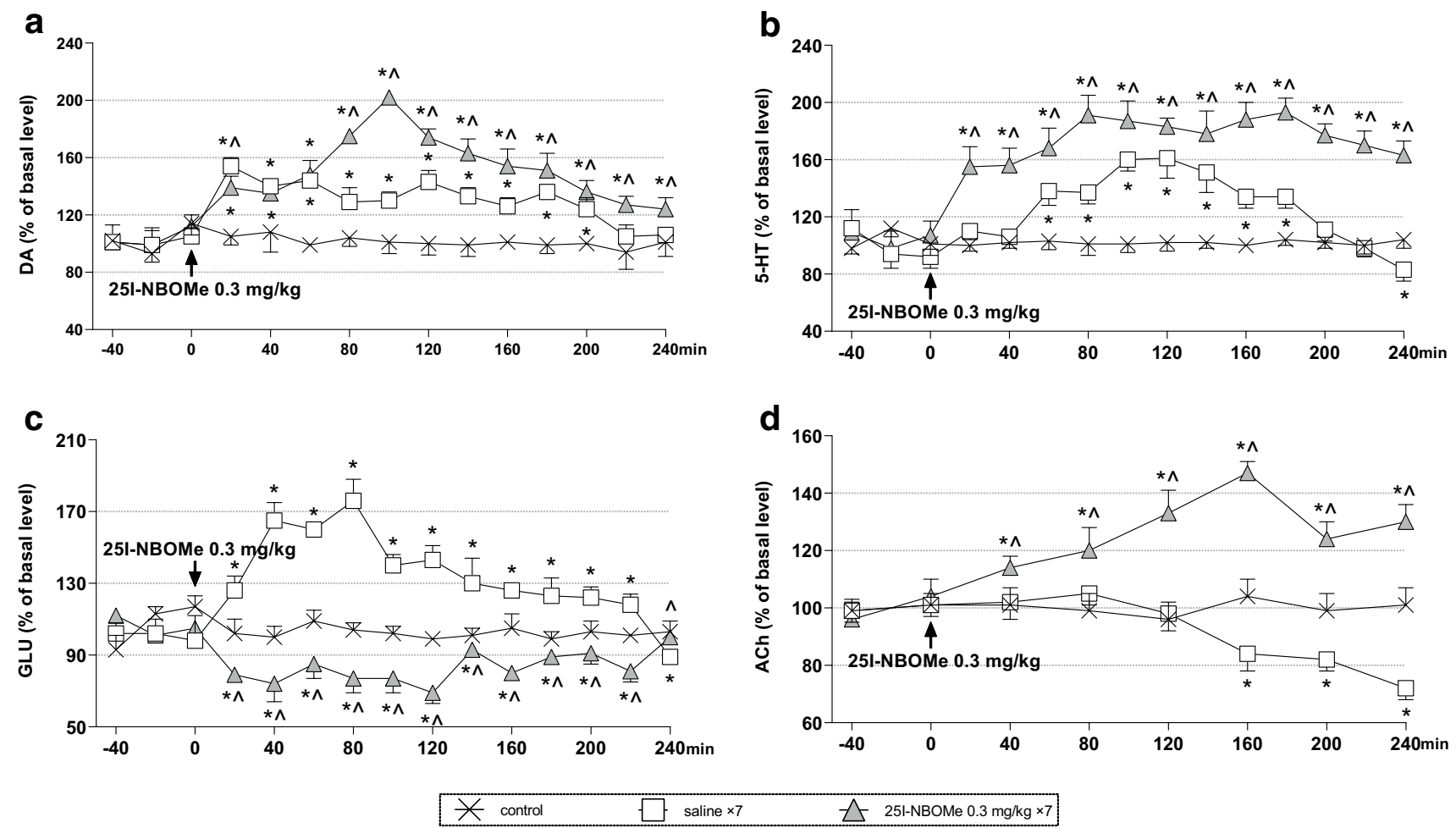

Fig. 2 The time-course effect of 25I-NBOMe on extracellular levels of dopamine (DA), serotonin (5-HT), glutamate (GLU), and acetylcholine $(\mathrm{ACh})$ in the rat striatum (a-d), respectively. Values are the mean \pm standard error of the mean (SEM), $n=6$ per experimental group. The drug injection is indicated with an arrow. $* p<0.01$ vs. control group; ${ }^{\wedge} p<0.01$ saline vs. repeated 25I-NBOMe administration (repeated measures ANOVA and Tukey's post hoc test) 


\section{N. ACCUMBENS}
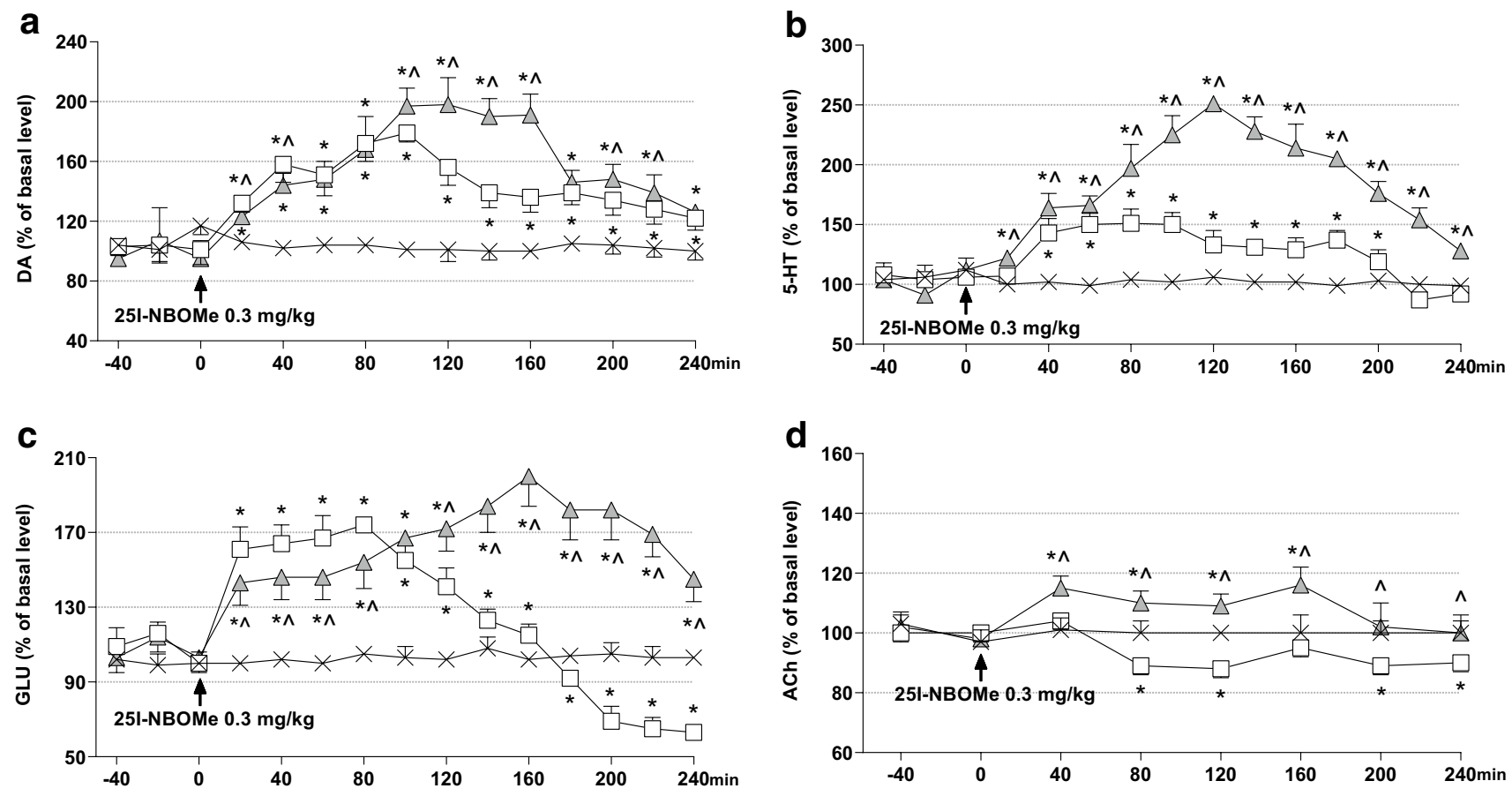

\begin{tabular}{lllll}
$*$ control & $\square$ saline $\times 7$ & $\searrow$ & 25l-NBOMe $0.3 \mathrm{mg} / \mathrm{kg} \times 7$ \\
\hline
\end{tabular}

Fig. 3 The time-course effect of 25I-NBOMe on extracellular levels of dopamine (DA), serotonin (5-HT), glutamate (GLU), and acetylcholine $(\mathrm{ACh})$ in the rat nucleus accumbens (a-d), respectively. Values are the mean \pm standard error of the mean (SEM), $n=6$ per

there was also an effect of time $\left(F_{11,165}=31, p<0.0001\right)$ and time $\times$ treatment interaction $\left(F_{22,165}=52, p<0.0001\right)$. The response of ACh neurons to a challenge dose of $0.3 \mathrm{mg} /$ $\mathrm{kg}$ increased in animals treated repeatedly for 7 days with 25I-NBOMe in comparison to acutely injected group (Fig. 3d). Repeated measures ANOVA showed an effect of treatment $\left(F_{2,15}=167, p<0.0001\right)$ and time $\left(F_{5,75}=16\right.$, $p<0.0001)$ on ACh levels, and a time $\times$ treatment interaction $\left(F_{10,75}=4.8, p<0.003\right)$.

\section{The total effect of acute and chronic administration of 25I-NBOMe on DA, 5-HT, ACh, and glutamate in the rat frontal cortex, striatum, and nucleus accumbens}

The summary of the total effect of 25I-NBOMe on DA, 5-HT, ACh, and glutamate in the rat frontal cortex, striatum, and nucleus accumbens, calculated as an area under the curve (AUC) and expressed as a percent of each basal level, is presented in Fig. 4a, b, c, and d. A repeated administration of 25I-NBOMe caused a weaker increase in DA, 5-HT, and glutamate levels in the frontal cortex and glutamate in the striatum in response to the challenge dose of experimental group. The drug injection is indicated with an arrow. * $p<0.01$ vs. control group; ${ }^{\wedge} p<0.01$ saline vs. repeated $25 \mathrm{I}-\mathrm{NBOMe}$ administration (repeated measures ANOVA and Tukey's post hoc test)

the drug in comparison to a single dose, whereas a more significant increase was observed in DA, 5-HT levels in the striatum and nucleus accumbens, glutamate in the nucleus accumbens, and ACh in all brain regions. Statistical data of one-way ANOVA analysis are presented in Table 1S (supplementary material).

\section{The effect of acute and chronic administration of 25I-NBOMe on the rats' behavior}

25I-NBOMe induced wet dog shake (WDS) response. The effect of repeated administration of $0.3 \mathrm{mg} / \mathrm{kg} 25 \mathrm{I}-\mathrm{BOMe}$ dose for 7 days was declining in time and remained at a similar low level from day 3 until day 7 (Fig. 5a). Repeated measures ANOVA showed a significant effect of treatment $\left(F_{1,28}=47.3, p<0.0001\right)$ and time $\left(F_{7,196}=34.8, p<0.0001\right)$, and a time $\times$ treatment interaction $\left(F_{7,196}=34.3, p<0.0001\right)$.

Locomotor activity of rats observed in the OF and expressed as the time of walking and the number of peeping episodes significantly decreased in groups treated repeatedly for 7 days with $0.3 \mathrm{mg} / \mathrm{kg}$ 25I-NBOMe dose in comparison to control and single-dose group (Fig. 5b). One-way 

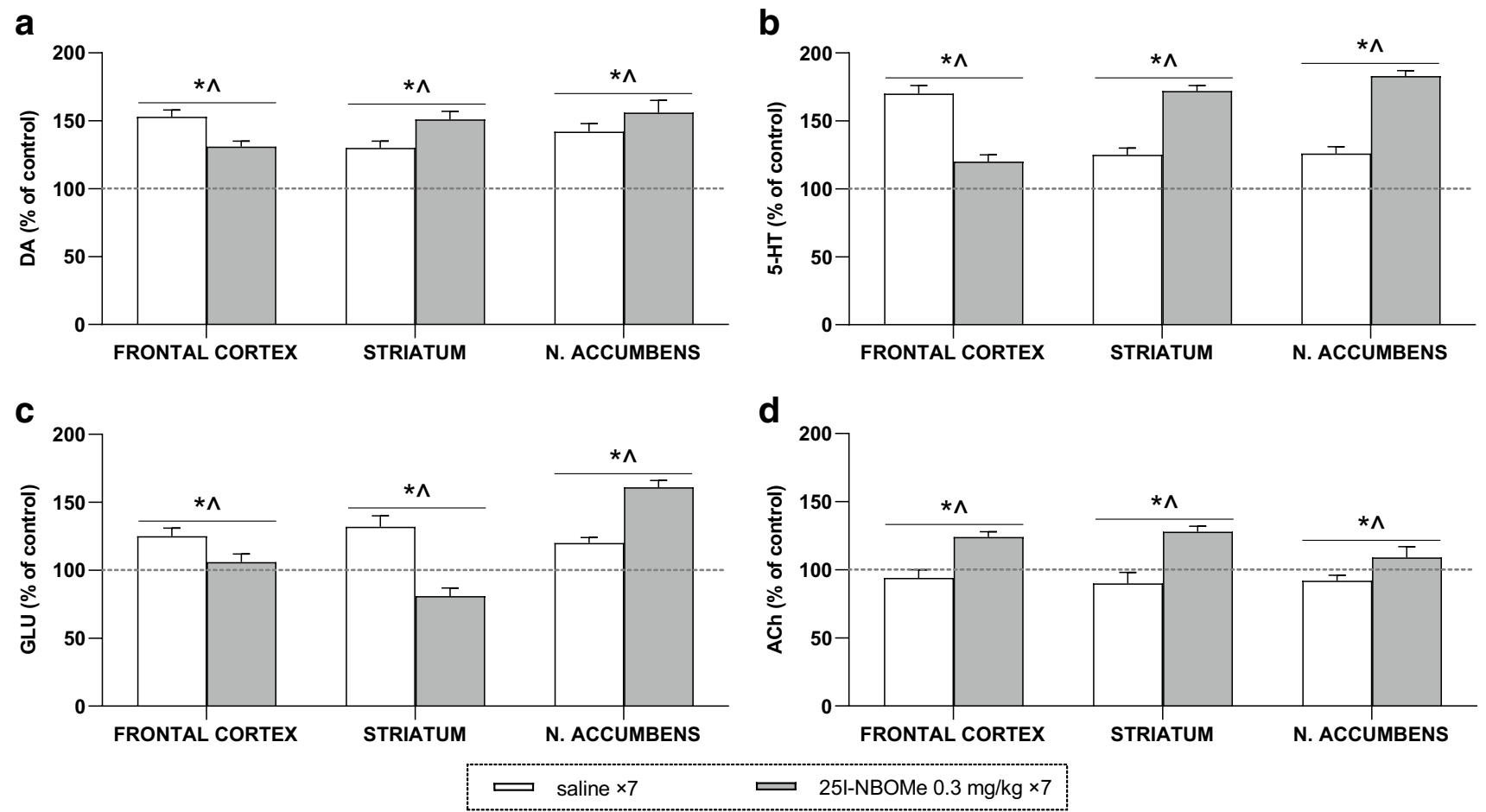

Fig. 4 The total effect of 25I-NBOMe on extracellular levels of dopamine (DA) in a, serotonin (5-HT) in b, glutamate (GLU) in $\mathbf{c}$ and acetylcholine $(\mathrm{ACh})$ in $\mathbf{d}$ in the rat frontal cortex, striatum, and nucleus accumbens calculated as an area under the concentrationtime curve (AUC) and expressed as the percent of control. Values are the mean \pm standard error of the mean (SEM), $n=6$ per experimental group. ${ }^{*} p<0.01$ vs. control group, ${ }^{\wedge} p<0.01$ saline vs. repeated 25I-NBOMe administration (one-way ANOVA and Tukey's post hoc test)

injections of 25I-NBOMe dose of $0.3 \mathrm{mg} / \mathrm{kg}(T=-28$, $p<0.02$ ) (Fig. 6a). The time spent in the dark zone in groups treated with the single and repeated doses of $0.3 \mathrm{mg} / \mathrm{kg}$ of $25 \mathrm{I}-\mathrm{NBOMe}$ was similar, but longer than in control $(U=0, U=2$, respectively; $p<0.0001)$. On the contrary, the time spent in the light zone was significantly decreased in groups of rats given single dose $(U=0, p<0.0001)$ or repeated doses of $0.3 \mathrm{mg} / \mathrm{kg}$ $(U=3, p<0.0001)$ in comparison to control (Fig. 6a). Exploration of the dark zone, expressed as ambulatory distance, vertical, and stereotypical activity, significantly decreased by single 25I-NBOMe dose of $0.3 \mathrm{mg} / \mathrm{kg}(U=18, p<0.04 ; U=1, p<0.0001 ; U=12$, $p<0.009$, respectively) in comparison to control, while in the groups treated repeatedly with $0.3 \mathrm{mg} / \mathrm{kg}$ of 25I-NBOMe, only the stereotypical activity time significantly increased with control rats $(U=2, p<0.0001)$ (Fig. 6b, c, d). Moreover, ambulatory distance, as well as vertical and stereotypical activity time in the light zone, decreased after single dose $(U=0, p<0.0001)$ and repeated doses of $0.3 \mathrm{mg} / \mathrm{kg}$ 25I-NBOMe (ambulatory distance: $U=3$; vertical activity: $U=1$; stereotypical activity: $U=2.5 ; p<0.0001)$ in comparison to control 

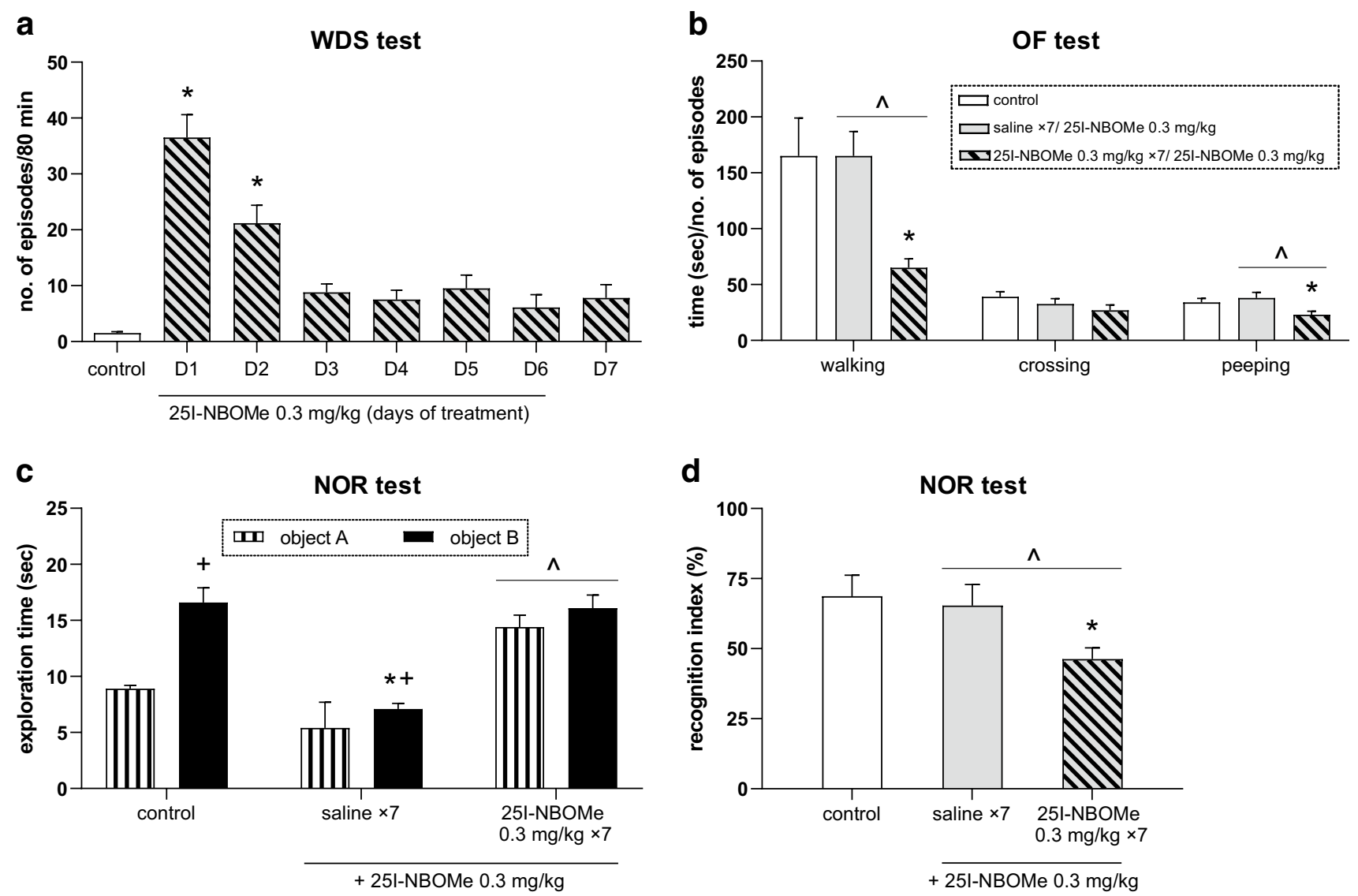

Fig. 5 The effect of 25I-NBOMe on wet dog shake response (WDS), on locomotor behavior in the open field (OF) test, and on performance of rats in the novel object recognition (NOR) test. a The number of WDS episodes counted for 80 min starting immediately after the injection. Values are the mean \pm standard error of the mean (SEM), $n=15$ per experimental group. $* p<0.001$ vs. control group (repeated measures ANOVA and Tukey's post hoc test). b The time spent on walking, number of crossing episodes, and number of peeping episodes in the OF test. Values are the mean \pm standard error of the mean (SEM), $n=11-12$ per experimental group. $* p<0.01$

rats. However, only in the dark zone, multiple injections of 25I-NBOMe significantly increased vertical activity time $(U=0, p<0.02)$ and stereotypical activity time $(U=0, p<0.0006)$ when compared with a single dose of $0.3 \mathrm{mg} / \mathrm{kg}$. The ambulatory distance in the light compartment was shorter for control $(T=-114, p<0.0004)$, and for rats administered a single dose $(T=-21, p<0.04)$ and chronic injections of 25I-NBOMe $(T=-28$, $p<0.02)$ in comparison to the dark compartment. Similarly, stereotypical activity time in the light zone decreased in comparison to the dark zone in all groups of animals (control: $T=-120, p<0.0001$; single dose: $T=-21, p<0.04$; repeated doses: $T=-28, p<0.02$ ). Furthermore, in the light compartment, vertical activity

time significantly decreased for animals treated with single dose $(T=-21, p<0.04)$ and repeated doses of $25 \mathrm{I}-\mathrm{NBOMe}(T=-28, p<0.02)$, when comparing to the vertical activity in the dark compartment (Fig. 6b, c, d).

\section{Discussion}

In the present work, we examined the effect of repeated administration of a low 25I-NBOMe dose on several neurotransmitters in the frontal cortex, striatum and nucleus accumbens, and hallucinogenic activity, locomotor activity, short-term memory, and anxiety in rats. 
Fig. 6 The effect of 25I-NBOMe on activity of rats in the light/dark box (LDB) test. a The time spent in the dark and light zone. b-d Ambulatory distance, vertical, and stereotypic activity, respectively in the dark and light zone. Values are the mean \pm standard error of the mean (SEM), $n=11-13$ per experimental group. * $p<0.04$ vs. control, $\wedge p<0.02$ vs. 25I-NBOMe $0.3 \mathrm{mg} / \mathrm{kg}$ (MannWhitney $U$ test), $+p<0.04$ light vs. dark zone (Wilcoxon $T$ test)

\section{LDB test}
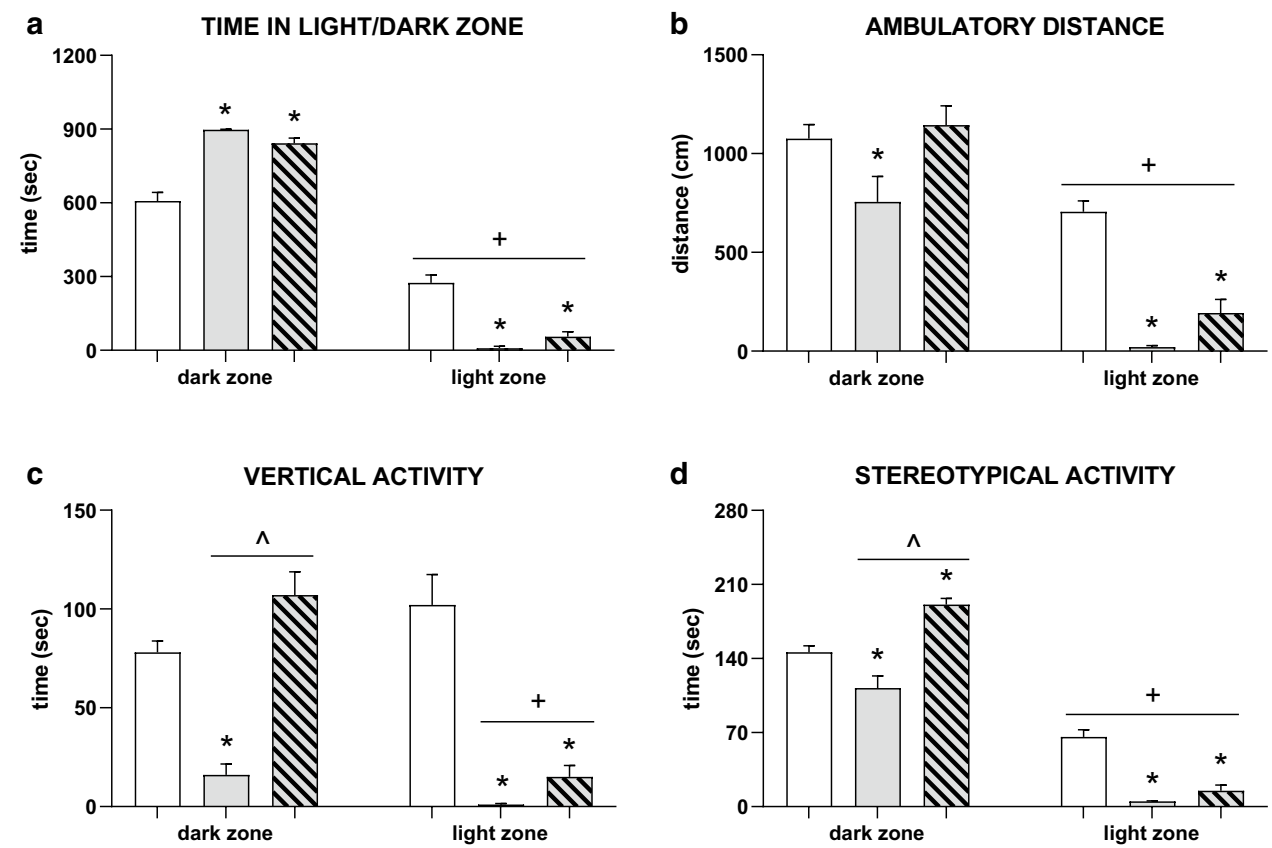

d

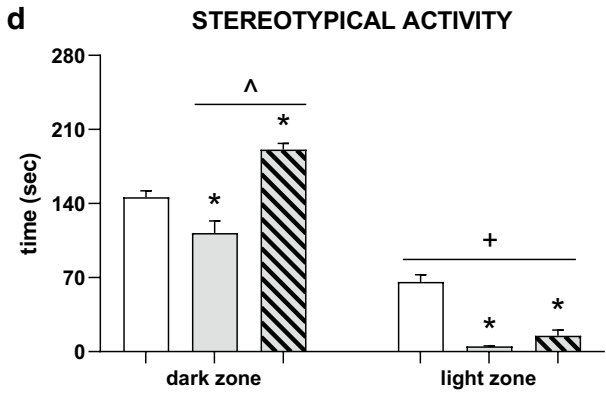

$\square$ control $\square$ saline $\times 7 / 251-N B O M e ~ 0.3 \mathrm{mg} / \mathrm{kg} \quad \square \nabla 25 \mathrm{I}-\mathrm{NBOMe} 0.3 \mathrm{mg} / \mathrm{kg} \times 7 / 25 \mathrm{l}-\mathrm{NBOMe} 0.3 \mathrm{mg} / \mathrm{kg}$

\section{Regulation of cortical glutamate, DA, and 5-HT release}

In contrast to acute administration, we found that a 7-day exposure to $0.3 \mathrm{mg} / \mathrm{kg}$ of 25I-NBOMe led to the reduced response of DA, 5-HT, and glutamate neurons to a challenge dose of the drug in the frontal cortex and to the reduced WDS counts. These neurochemical and behavioral data indicate tolerance development observed from the third day of administration in the WDS test. The observed changes in the activity of neurotransmitters and animal behavior suggest the development of tolerance, which seems to result from 5- $\mathrm{HT}_{2 \mathrm{~A}}$ receptors' downregulation and their desensitization (Nichols 2016). Buckholtz et al. (1990) reported a decrease in $5-\mathrm{HT}_{2}$ receptor density in the rat brain after multiple injections of LSD. Damjanoska et al. (2004) found that a 7-day treatment with DOI decreased 5-HT-stimulated PLC activity in the frontal cortex; it is suggested that desensitization of $5-\mathrm{HT}_{2 \mathrm{~A}}$ receptors is most likely attributable to post-translational modifications of the receptor due to a change in $5-\mathrm{HT}_{2 \mathrm{~A}}$ receptor coupling to $\mathrm{G}$ proteins.

This phenomenon is common to serotonergic hallucinogens, and close congeners in this class shared it: $25 \mathrm{CN}-$ NBOH or LSD and DOM (Buchborn et al. 2018; Buckholtz et al. 1990; Gresch et al. 2005). Multiple studies have demonstrated that cortical $5-\mathrm{HT}_{2 \mathrm{~A}}$ receptors are localized primarily in apical dendrites of pyramidal neurons with a minor localization to GABAergic interneurons (Miner et al. 2003; Willins et al. 1997). It is proposed that changes in glutamate release parallel hallucinogenic activity and this is a common mechanism in the action of hallucinogens (Herian et al. 2018; Herian et al. 2019; Muschamp et al. 2004; NoworytaSokolowska et al. 2016; Scruggs et al. 2003). This effect results from the activation of $5-\mathrm{HT}_{2 \mathrm{~A}}$ receptors located on cortical pyramidal cells since their blockade with the selective antagonist M100907 reduced WDS and cortical glutamate release (Herian et al. 2020; Scruggs et al. 2003). A rapid loss of $5-\mathrm{HT}_{2 \mathrm{~A}}$ receptor responsiveness seems to cause a desensitization of $5-\mathrm{HT}_{2 \mathrm{~A}}$ receptor-mediated glutamate release in the frontal cortex. Consequently, glutamatergic efferents which innervate dopaminergic and serotonergic cells projecting to the cortex (Alex and Pehek 2007; Di Matteo et al. 2008; Martin-Ruiz et al. 2001) may be responsible for the decreased release from cortical DA and 5-HT terminals observed in our study after repeated 25I-NBOMe treatment.

\section{Regulation of glutamate, DA, and 5-HT release in the striatum and nucleus accumbens}

Immunohistochemical studies have indicated a low density of 5- $\mathrm{HT}_{2 \mathrm{~A}}$ receptors in the VTA and substantia nigra (SN) presumably distributed on GABAergic cells (Alex and Pehek 2007). Furthermore, receptor binding studies demonstrated a high level of 5- $\mathrm{HT}_{2 \mathrm{~A}}$ receptors in the striatum localized on 
afferents arising mainly from the cortex and globus pallidus (Bubser et al. 2001). Both striato-pallidal and striato-nigral neurons also express 5- $\mathrm{HT}_{2 \mathrm{~A}}$ receptors (Ward and Dorsa 1996). In our study, DA and 5-HT neurons in the striatum and nucleus accumbens responded with increased strength to a challenge dose in animals pretreated repeatedly with 25I-NBOMe, in comparison to the acutely injected group. These data allow us to hypothesize that tolerant 5- $\mathrm{HT}_{2 \mathrm{~A}}$ receptors located on efferent GABAergic neurons or VTA/ SN GABAergic interneurons exert a weaker stimulating effect on GABA release. Thus, disinhibition of dopamine neurons from GABAergic control may result in higher extracellular levels of DA in response to a challenge dose observed in the striatum and nucleus accumbens. These findings are in line with a recent study by Custodio et al. (2019), who demonstrated that 7 days of treatment with a close congener of this class of compound, 25B-NBOMe, increased DA level in the nucleus accumbens of mice. It is also known that serotonergic dorsal raphe cells, which send projections to the prefrontal cortex, striatum, and nucleus accumbens (Di Matteo et al. 2008), are controlled by cortical pyramidal cells (Martin-Ruiz et al. 2001). In addition, descending glutamatergic pathways may indirectly inhibit raphe cells by stimulation of GABAergic interneurons (Di Matteo et al. 2008; Martin-Ruiz et al. 2001). Desensitization of 5-HT $2 \mathrm{~A}$ receptors by repeated administration of 25I-NBOMe may exert a weaker effect on GABA interneurons in comparison to a single dose leading to higher extracellular levels of 5-HT in response to a challenge dose, as it is observed in the striatum and nucleus accumbens. Moreover, it needs to be mentioned that basal 5-HT levels in the striatum of rats treated repeatedly with 25I-NBOMe decreased in comparison to the control group (Table $2 \mathrm{~S}$, supplementary material). Therefore, the response of local $5-\mathrm{HT}_{2 \mathrm{~A}}$ receptors to the 25I-NBOMe challenge dose could be stronger to compensate for the reduction in basal neurotransmitter level.

It has been suggested that $5-\mathrm{HT}_{2 \mathrm{~A}}$ receptors localized on cortico-striatal axons can regulate glutamatergic activity in the striatum (Ansah et al. 2011). Similarly, 5- $\mathrm{HT}_{2 \mathrm{~A}}$ receptors localized on pyramidal cells projecting to the nucleus accumbens may be responsible for glutamate release in this region (Aghajanian and Marek 1997). Interestingly, in our study, the response of glutamate neurons to a challenge dose was weaker in the striatum but more potent in the nucleus accumbens in rats treated repeatedly with 25I-NBOMe in comparison to the acutely injected group. This divergent effect may be related to inhibitory $D_{2}$ receptors present on cortico-striatal/cortico-accumbal glutamatergic terminals (Cepeda et al. 2001; Del Arco and Mora 2008; Maura et al. 1988). Presynaptic modulation of glutamate release along the cortico-striatal pathway was enhanced in $\mathrm{D}_{2}$ receptor knock-out animals; thus, $\mathrm{D}_{2}$ receptors function to decrease glutamate release in the dorsal striatum (Cepeda et al. 2001). The decrease in basal DA striatal levels in repeatedly injected rats may affect the sensitivity of $\mathrm{D}_{2}$ receptors in their inhibitory control of glutamate release leading to a strong reduction in extracellular glutamate level compared to a single dose (Table $2 \mathrm{~S}$, supplementary material). In contrast, an increased response of glutamatergic terminals in the nucleus accumbens to a challenge dose in repeatedly 25I-NBOMe-treated animals compared to a single dose may instead result from disinhibition of glutamate corticoaccumbal neurons from GABAergic control.

\section{Regulation of ACh release in the frontal cortex, striatum, and nucleus accumbens}

Basal forebrain projections constitute a majority of cholinergic innervation to the cortex (Lebois et al. 2018). It generally appears that 5-HT exerts a stimulatory influence on the release of ACh (Saito et al. 1996). On the other hand, 5-HT has been shown to inhibit cholinergic neurons in the pedunculopontine and dorsolateral tegmental neurons, which express 5- $\mathrm{HT}_{2 \mathrm{~A}}$ receptors (Koyama and Kayama 1993). Thus, the effect of 5-HT on the cholinergic system depends on the receptor localization, making the regulation very complex. Authors of one study showed that the $5-\mathrm{HT}_{2 \mathrm{~A} / 2 \mathrm{C}}$ agonist DOI as well as mescaline enhanced ACh release in the rat mPFC (Nair and Gudelsky 2004). The striatum and nucleus accumbens contain numerous cholinergic interneurons (Meredith and Wouterlood 1990). It was shown that $5-\mathrm{HT}_{2 \mathrm{~A}}$ receptors mediated depolarization-induced $\mathrm{ACh}$ release from cholinergic interneurons in the striatum, but in the ventral part of this region, cholinergic interneurons were hyperpolarized by $5-\mathrm{HT}$ acting at $5-\mathrm{HT}_{1 \mathrm{~A} / 1 \mathrm{~B}}$ receptors (Blomeley and Bracci 2005; Bonsi et al. 2007; Virk et al. 2016). Moreover, there are DA and ACh relationships in the striatum and nucleus accumbens, as DA inhibits ACh release acting at $\mathrm{D}_{2}$ receptors expressed on cholinergic interneurons, while stimulation of $A C h$ release via $D_{1}$ receptors needs a higher concentration of the agonist (Straub et al. 2014; Wedzony et al. 1988). In our present work, 25I-NBOMe administered repeatedly increased ACh release in the frontal cortex, striatum, and nucleus accumbens in response to a challenge drug dose. In contrast, a single dose of 25I-NBOMe slightly but significantly decreased ACh release in all the brain regions studied. The inhibitory effect of single doses may be mediated indirectly through dopamine $\mathrm{D}_{2}$ receptors located in striatal and accumbal cholinergic interneurons and activated by $5-\mathrm{HT}_{2 \mathrm{~A}}$ receptor-mediated DA release. The increase in ACh release by repeated administration of 25I-NBOMe in all the brain regions studied seems to be related to $5-\mathrm{HT}_{2 \mathrm{~A}}$ receptors, as also shown elsewhere (Nair and Gudelsky 2004). 


\section{The effect on animal behavior}

25I-NBOMe reduced motor activity of rats evaluated in the $\mathrm{OF}$ test. The time of walking and the number of peeping episodes were lower in animals treated repeatedly with 25I-NBOMe than in saline control or acute 25I-NBOMe $0.3 \mathrm{mg} / \mathrm{kg}$ groups. Control of animal movement is mediated through both striato-pallidal and striato-nigral GABAergic medium-sized spiny neurons (MSN), which express dopamine $D_{1}$ and $D_{2}$ (Alex and Pehek 2007; Gerfen et al. 1990) and serotonin 5- $\mathrm{HT}_{2 \mathrm{~A}}$ receptors (Ansah et al. 2011). However, heteroreceptors located on the terminals of the cortico-striatal glutamatergic axons appear to be the significant source of 5- $\mathrm{HT}_{2 \mathrm{~A}}$ receptors (Bubser et al. 2001). Since glutamate and DA inputs terminate on the same MSN spines, these sites offer the potential for physiological interactions between the glutamate and DA transmitter systems (Freund et al. 1984). The state of activation of the $\mathrm{D}_{1}$ direct and $\mathrm{D}_{2}$ indirect GABAergic pathways depends on the amount of extracellular DA. In turn, DA release depends on $5-\mathrm{HT}_{2 \mathrm{~A}^{-}}$ mediated glutamate levels stimulating the striatal NMDA receptors (Cepeda et al. 1993). As evidenced in our study, the disturbed balance between DA and glutamate levels in the striatum by repeated 25I-NBOMe administration may cause insufficient activation of the $\mathrm{D}_{1}$ receptor-expressing direct pathway and $\mathrm{D}_{2}$ receptor-expressing indirect pathway projecting to the SN pars reticulata and the internal globus pallidus and subthalamic nucleus, respectively (Gerfen et al. 1990) resulting in disrupted rats' motor performance. Moreover, Del Arco et al. (2007) presented reduced spontaneous motor activity of rats in OF after stimulation of prefrontal $\mathrm{D}_{2}$ receptors in relation to DA release in the nucleus accumbens. The decrease in the basal DA levels in the striatum observed in our study may account for the reduction of motor activity of rats in OF after repeated administration of 25I-NBOMe. Significantly, the activity of MSN neurons is also regulated by muscarinic receptors. The direct GABAergic striatal output pathway contains both excitatory $\mathrm{M}_{1}$ and inhibitory $\mathrm{M}_{2}$ muscarinic receptors, while the indirect pathway primarily has $\mathrm{M}_{1}$ receptors (Singer and Minzer 2003). 25I-NBOMeinduced increase in $\mathrm{ACh}$ release causing deregulation of striatal output pathways may also contribute to the reduced rats' motor activity in the $\mathrm{OF}$ test. It has to be mentioned that antimuscarinic drugs are administered in the treatment of motor symptoms of Parkinson's disease (Pisani et al. 2007).

Besides the striatum, where functional glutamate-DA interactions are crucial in motor control, these interactions in the frontal cortex are implicated in working memory and cognition. In our study, the exploration of a novel object in the NOR test was disturbed by all treatments. However, the exploration time of animals pretreated with repeated doses of 25I-NBOMe was longer; yet, animals did not differentiate between the familiar and novel object. The decrease in $R i$ in the group repeatedly treated with 25I-NBOMe suggests a deficit in memory processing. The evidence from several studies has suggested the critical involvement of the $5-\mathrm{HT}_{2 \mathrm{~A}}$ receptors in the prefrontal cortex activity and its cognitive functions, such as working memory and attention (Zhang and Stackman 2015). The role of the 5- $\mathrm{HT}_{2 \mathrm{~A}}$ receptor was evidenced by a study in which systemic activation of the $5-\mathrm{HT}_{2 \mathrm{~A}}$ receptor by an agonist significantly enhanced the time the mice spent exploring the new object presented during the test session $24 \mathrm{~h}$ later (Zhang et al. 2013). The relevance of the $5-\mathrm{HT}_{2 \mathrm{~A}}$ receptor for object memory processes was also demonstrated by the results of a study proving that the local infusion of the 5- $\mathrm{HT}_{2 \mathrm{~A}}$ receptor antagonist MDL 11,939 into the medial prefrontal cortex impaired retrieval of the object-in-context memory in rats (Bekinschtein et al. 2013). These data suggest that $5-\mathrm{HT}_{2 \mathrm{~A}}$ receptor activation potentiates memory consolidation. Furthermore, it was proven that $5-\mathrm{HT}_{2 \mathrm{~A}}$ receptor activation increased the extracellular efflux of glutamate in the dorsal hippocampus suggesting that memory consolidation might result from the potentiation of glutamate release in this region (Zhang and Stackman 2015). The data of Zhang and Stackman Jr. (2015) points out that hippocampus interaction with the frontal cortex also plays an important role in memory performance. Recognition of a novel object seems to depend on a functional interaction between the hippocampus and the perirhinal or medial prefrontal cortices (Barker and Warburton 2011). Therefore, it may be hypothesized that the memory impairment demonstrated in our study in 25I-NBOMe-repeatedly treated rats may result from the decreased activity of $5-\mathrm{HT}_{2 \mathrm{~A}}$ receptormediated glutamate release in the frontal cortex in comparison to the acutely injected group. Furthermore, it has been evidenced that ACh cortical function has been linked to the control of circuits underlying attention and memory (Deepak et al. 2012; Picciotto et al. 2012). Havekes et al. (2011) suggest that the striatal cholinergic system is also significant for learning and memory through interactions with dopaminergic and GABAergic systems. It is well established that cholinergic dysfunction accompanies a cognitive decline in Alzheimer's disease. The increased ACh release observed in our study stands in contradiction to the results of the NOR test showing memory impairment by repeated treatment with 25I-NBOMe. However, the increase in ACh levels is not very potent compared to control and might be less meaningful for memory processes than glutamate decrease.

Halberstadt and Geyer (2018) reported that some phenylethylamine and indoleamine hallucinogens reduced rats' locomotor activity in unfamiliar environments, which suggested that this effect reflected the fear in novel settings and increased center avoidance induced by hallucinogens reminding agoraphobia observed in humans. Our results from the LDB test agree with the above findings since animals pretreated with single and repeated doses 
of 25I-NBOMe spent more time in the dark compartment, while the time spent in the light compartment was shorter in comparison to the control rats. These data suggest that 25I-NBOMe administered in either single or repeated doses of $0.3 \mathrm{mg} / \mathrm{kg}$ is likely to induce anxiety in animals. Similarly, the reduction of the open arm entries in the elevated plus maze test after subchronic intermittent injections of low doses of ketamine and psilocin points to a mildly anxiogenic behavioral profile (Horsley et al. 2018). However, in contrast to a single dose, 25I-NBOMe administered repeatedly increased vertical and stereotypical activity in the dark zone. These results are contradictory to our findings in the $\mathrm{OF}$ test. This difference may result from the setting of the test. The animals seemed to be afraid of the open arena while they were actively exploring closed space, what indicates a biphasic locomotor profile. It may be suggested that the environment may have an impact on the manner in which psychedelics affect animals' strategies to cope with fear.

The neurochemical data from our study indicate that the changes in neurotransmitter levels induced by 25I-NBOMe may be implicated in symptoms of anxiety in the LDB test. Some research suggests that DA may be related to social phobia and obsessive-compulsive disorder. Low levels of 5-HT are also believed to play a role in anxiety stimulation (Martin et al. 2009). Animal models and human clinical drug trials have demonstrated that drugs, through altering glutamate transmission, produce a potential anxiolytic action in many different paradigms (Cortese and Phan 2005). We observed changes in extracellular DA, 5-HT, and glutamate levels in all studied brain regions under the influence of 25I-NBOMe. The enhanced DA levels in the striatum and nucleus accumbens may be responsible for a marked increase in the vertical and stereotypical activity of animals after repeated treatment with 25I-NBOMe compared to a single dose. On the other hand, the decreased response of 5-HT in the frontal cortex under repeated 25I-NBOMe dosing regimen might be connected with light zone avoidance by rats and may indicate an elevated anxiety level. Desensitization of the $5-\mathrm{HT}_{2 \mathrm{~A}}$ receptor resulting in the decreased response of cortical glutamate pathways and hyperactive limbic neuronal systems may constitute the background mechanism of anxiogenic effects of 25I-NBOMe in the LDB test.

\section{Conclusions and limitations}

In conclusion, repeated treatment with a low dose of 25I-NBOMe induced a decline in WDS and loss of responsiveness of DA, 5-HT, and glutamate neuronal pathways in the rat frontal cortex to a challenge dose of 25I-NBOMe compared to a single administration. The changes in DA, 5-HT, ACh, and glutamate levels in the striatum and nucleus accumbens seem to depend on the activity of the $5-\mathrm{HT}_{2 \mathrm{~A}}$ receptor on cortical pyramidal cells since blockade of this receptor with selective antagonist reversed the effect of 25I-NBOMe, as evidenced in our recent study (Herian et al. 2020). The mechanism of the 25I-NBOMe-induced impairment of several behavioral functions, such as locomotor activity, short-term memory, and anxiety, seems to be more complex and result from a modulatory role of distinct receptor populations in regions controlled by cortical projections. The precise identification of receptors controlling the behavioral response to repeated treatment with a low dose of 25I-NBOMe needs further studies.

Supplementary Information The online version contains supplementary material available at https://doi.org/10.1007/s00213-021-05860-5.

Acknowledgements The authors would like to thank Dr. Rafał Ryguła for valuable comments on behavioral data.

Funding This study was supported by the National Science Centre, Kraków, Poland (grant no. 2016/21/B/NZ7/01131) and statutory fund of the Maj Institute of Pharmacology of the Polish Academy of Sciences. MH received support from InterDokMed project no. POWR.03.02.00-00-I013/16. The funding sources had no role in the design of the study, data collection, data analysis, or decision to publish.

\section{Declarations}

All animal use procedures were conducted in strict accordance with the European regulations for animal experimentation (EU Directive 2010/63/ EU on the Protection of Animals Used for Scientific Purposes). The experimental protocols were approved by the Local Ethics Commission for Experimentation on Animals (permit numbers: 186/2017 and 188/2017).

Conflict of interest The authors declare no competing interests.

Open Access This article is licensed under a Creative Commons Attribution 4.0 International License, which permits use, sharing, adaptation, distribution and reproduction in any medium or format, as long as you give appropriate credit to the original author(s) and the source, provide a link to the Creative Commons licence, and indicate if changes were made. The images or other third party material in this article are included in the article's Creative Commons licence, unless indicated otherwise in a credit line to the material. If material is not included in the article's Creative Commons licence and your intended use is not permitted by statutory regulation or exceeds the permitted use, you will need to obtain permission directly from the copyright holder. To view a copy of this licence, visit http://creativecommons.org/licenses/by/4.0/.

\section{References}

Aghajanian GK, Marek GJ (1997) Serotonin induces excitatory postsynaptic potentials in apical dendrites of neocortical pyramidal cells. Neuropharmacology 36:589-599. https://doi.org/10.1016/ S0028-3908(97)00051-8

Alex KD, Pehek EA (2007) Pharmacologic mechanisms of serotonergic regulation of dopamine neurotransmission. Pharmacol Ther 113:296-320. https://doi.org/10.1016/jpharmthera200608004

Ansah TA, Ferguson MC, Nayyar T (2011) The 5-HT(2A) receptor antagonist M100907 produces antiparkinsonian effects and decreases striatal glutamate. Front Syst Neurosci 5:48. https://doi. org/10.3389/fnsys 201100048 
Antunes M, Biala G (2012) The novel object recognition memory: neurobiology test, procedure, and its modifications. Cogn Process 13:93-110. https://doi.org/10.1007/s10339-011-0430-z

Barker GRI, Warburton EC (2011) When is the hippocampus involved in recognition memory? J Neurosci 31:10721-10731. https://doi. org/10.1523/jneurosci.6413-10.2011

Begola MJ, Schillerstrom JE (2019) Hallucinogens and their therapeutic use. J Psychiatr Pract 25:334-346. https://doi.org/10.1097/ pra0000000000000409

Bekinschtein P, Renner MC, Gonzalez MC, Weisstaub N (2013) Role of medial prefrontal cortex serotonin $2 \mathrm{~A}$ receptors in the control of retrieval of recognition memory in rats. J Neurosci 33:15716-15725. https://doi.org/10.1523/JNEUROSCI2 087-132013

Blomeley C, Bracci E (2005) Excitatory effects of serotonin on rat striatal cholinergic interneurons. J Physiol 569:715-721. https:// doi.org/10.1113/jphysiol2005098269

Bogenschutz MP, Ross S (2018) Therapeutic applications of classic hallucinogens. In: Halberstadt AL, Vollenweider FX, Nichols DE (eds) Curr Top Behav Neurosci 36: Behavioral neurobiology of psychedelic drugs. Springer-Verlag GmbH, Berlin, pp 361-391. https://doi.org/10.1007/7854_2016_464

Bonsi P, Cuomo D, Ding J, Sciamanna G, Ulrich S, Tscherter A, Bernardi G, Surmeier DJ, Pisani A (2007) Endogenous serotonin excites striatal cholinergic interneurons via the activation of 5-HT2C, 5-HT6, and 5-HT7 serotonin receptors: implications for extrapyramidal side effects of serotonin reuptake inhibitors. Neuropsychopharmacology 32:1840-1854. https://doi.org/10. 1038/sjnpp1301294

Bubser M, Backstrom JR, Sanders-Bush E, Roth BL, Deutch AY (2001) Distribution of serotonin 5-HT(2A) receptors in afferents of the rat striatum. Synapse 39:297-304. https://doi.org/ 10.1002/1098-2396(20010315)39:4\%3c297::AID-SYN1012\% $3 \mathrm{e} 30 \mathrm{CO} ; 2-\mathrm{Q}$

Buchborn T, Lyons T, Knöpfel T (2018) Tolerance and tachyphylaxis to head twitches induced by the 5-HT2A agonist $25 \mathrm{CN}-\mathrm{NBOH}$ in mice. Front Pharmacol 9:17. https://doi.org/10.3389/fphar20180 0017

Buckholtz NS, Zhou DF, Freedman DX, Potter WZ (1990) Lysergic acid diethylamide (LSD) administration selectively downregulates serotonin2 receptors in rat brain. Neuropsychopharmacology $3: 137-148$

Carhart-Harris RL, Roseman L, Bolstridge M, Demetriou L, Pannekoek JN, Wall MB, Tanner M, Kaelen M, McGonigle J, Murphy K, Leech R, Curran HV, Nutt DJ (2017) Psilocybin for treatmentresistant depression: fMRI-measured brain mechanisms. Sci Rep 7:13187. https://doi.org/10.1038/s41598-017-13282-7

Cepeda C, Buchwald NA, Levine MS (1993) Neuromodulatory actions of dopamine in the neostriatum are dependent upon the excitatory amino acid receptor subtypes activated. Proc Natl Acad Sci USA 90:9576-9580. https://doi.org/10.1073/pnas90209576

Cepeda C, Hurst R, Altemus K, Flores-Hernandez J, Calvert C, Jokel E, Grandy D, Low M, Rubinstein M, Ariano MA, Levine M (2001) Facilitated glutamatergic transmission in the striatum of D2 dopamine receptor mice. J Neurophysiol 85:659-670. https://doi.org/ $10.1152 /$ jn2001852659

Cortese BM, Phan KL (2005) The role of glutamate in anxiety and related disorders CNS. Spectr 10:820-830. https://doi.org/10. 1017/S1092852900010427

Custodio RJP, Sayson LV, Botanas CJ, Abiero A, You KY, Kim M, Lee HJ, Yoo SY, Lee KW, Lee YS, Seo JW, Ryu IS, Kim HJ, Cheong JH (2019) 25B-NBOMe, a novel N-2-methoxybenzylphenethylamine (NBOMe) derivative, may induce rewarding and reinforcing effects via a dopaminergic mechanism: evidence of abuse potential. Addict Biol 25:e12850. https://doi.org/10.1111/ adb12850
Damjanoska KJ, Heidenreich BA, Kindel GH, D'Souza DN, Zhang Y, Garcia F, Battaglia G, Wolf WA, Van de Kar LD, Muma NA (2004) Agonist-induced serotonin 2A receptor desensitization in the rat frontal cortex and hypothalamus. J Pharmacol Exp Ther 309:1043-1050. https://doi.org/10.1124/jpet.103.062067

Deepak M, Tripathi AS, Wadhwani PJ, Shriao AV, Chandewar AV (2012) Neurobiological modulators of anxiety. IRJP 3:60-64

Del Arco A, Mora F (2008) Prefrontal cortex-nucleus accumbens interaction: in vivo modulation by dopamine and glutamate in the prefrontal cortex. Pharmacol Biochem Behav 90:226-235. https:// doi.org/10.1016/jpbb200804011

Del Arco A, Mora F, Mohammed AH, Fuxe K (2007) Stimulation of $\mathrm{D} 2$ receptors in the prefrontal cortex reduces PCP-induced hyperactivity, acetylcholine release and dopamine metabolism in the nucleus accumbens. J Neural Transm (Vienna) 114:185-193. https://doi.org/10.1007/s00702-006-0533-3

Di Matteo V, Di Giovanni G, Pierucci M, Esposito E (2008) Serotonin control of central dopaminergic function: focus on in vivo microdialysis studies. Prog Brain Res 172:7-44. https://doi.org/10.1016/ S0079-6123(08)00902-3

Elmore JS, Decker AM, Sulima A, Rice KC, Partilla JS, Blough BE, Baumann MH (2018) Comparative neuropharmacology of $\mathrm{N}$-(2-methoxybenzyl)-25-dimethoxyphenethylamine (NBOMe) hallucinogens and their $2 \mathrm{C}$ counterparts in male rats. Neuropharmacology 142:240-250. https://doi.org/10.1016/jneurophar m201802033

Fantegrossi WE, Murnane KS, Reissig CJ (2008) The behavioral pharmacology of hallucinogens. Biochem Pharmacol 75:17-33. https://doi.org/10.1016/jbcp200707018

Freund TF, Powell JF, Smith AD (1984) Tyrosine hydroxylase-immunoreactive boutons in synaptic contact with identified striatonigral neurons, with particular reference to dendritic spines. Neuroscience 13:1189-1215. https://doi.org/10.1016/0306-4522(84) 90294-x

Gatch MB, Dolan SB, Forster MJ (2017) Locomotor and discriminative stimulus effects of four novel hallucinogens in rodents. Behav Pharmacol 28:375-385. https://doi.org/10.1097/FBP00 00000000000309

Gerfen CR, Engber TM, Mahan LC, Susel Z, Chase TN, Monsma FJ Jr, Sibley DR (1990) D1 and D2 dopamine receptor-regulated gene expression of striatonigral and striatopallidal neurons. Science 250:1429-1432. https://doi.org/10.1126/science2147780

Glennon RA, Titeler M, McKenney JD (1984) Evidence for 5-HT2 involvement in the mechanism of action of hallucinogenic agents. Life Sci 35:2505-2511. https://doi.org/10.1016/0024-3205(84)90436-3

Gresch PJ, Smith RL, Barrett RJ, Sanders-Bush E (2005) Behavioral tolerance to lysergic acid diethylamide is associated with reduced serotonin-2A receptor signaling in rat cortex. Neuropsychopharmacology 30:1693-1702. https://doi.org/10.1038/sjnpp1300711

Grob CS, Danforth AL, Chopra GS, Hagerty M, McKay CR, Halberstadt AL, Greer GR (2011) Pilot study of psilocybin treatment for anxiety in patients with advanced-stage cancer. Arch Gen Psychiatry 68:71-80. https://doi.org/10.1001/archgenpsychiatry2010116

Halberstadt AL (2015) Recent advances in the neuropsychopharmacology of serotonergic hallucinogens. Behav Brain Res 277:99-120. https://doi.org/10.1016/jbbr201407016

Halberstadt AL (2017) Pharmacology and toxicology of N-benzylphenethylamine ("NBOMe") hallucinogens. In: Baumann MH, Glennon RA, Wiley JL (eds) Curr Top Behav Neurosci 32: Neuropharmacology of new psychoactive substances. Springer Nature, Cham, pp 283-311. https://doi.org/10.1007/7854_2016_64

Halberstadt AL, Geyer MA (2018) Effect of hallucinogens on unconditioned behavior. In: Halberstadt AL, Vollenweider FX, Nichols DE (eds) Curr Top Behav Neurosci 36: Behavioral neurobiology of psychedelic drugs. Springer-Verlag GmbH, Berlin, pp 159-199. https://doi.org/10.1007/7854_2016_466 
Havekes R, Abel T, Van der Zee EA (2011) The cholinergic system and neostriatal memory functions. Behav Brain Res 221:412-423. https://doi.org/10.1016/jbbr201011047

Herian M, Kaminska K, Wojtas A, Swit P, Golembiowska K (2018) Comparison between LSD and 25-I-NBOMe effects on brain neurotransmitters and WDS response in rats. In: 14th International Symposium Molecular basis of pathology and therapy in neurological disorders, Folia Neuropathologica 56/3 264. https://doi. org/10.5114/fn201878705

Herian M, Wojtas A, Kaminska K, Swit P, Wach A, Golembiowska K (2019) Hallucinogen-like action of the novel designer drug 25I-NBOMe and its effect on cortical neurotransmitters in rats. Neurotox Res 36:91-100. https://doi.org/10.1007/ s12640-019-00033-x

Herian M, Wojtas A, Sobocinska MK, Skawski M, Gonzalez-Marin A, Golembiowska K (2020) Contribution of serotonin receptor subtypes to hallucinogenic activity of 25I-NBOMe and to its effect on neurotransmission. Pharmacol Rep 72:1593-1603. https://doi. org/10.1007/s43440-020-00181-4

Horsley RR, Palenicek T, Kolin J, Vales K (2018) Psilocin and ketamine microdosing: effects of subchronic intermittent microdoses in the elevated plus-maze in male Wistar rats. Behav Pharmacol 29:530-536. https://doi.org/10.1097/FBP0000000000000394

Jeon SY, Kim YH, Kim SJ, Suh SK, Cha HJ (2019) Abuse potential of 2-(4-iodo-25-dimethoxyphenyl)-N-(2-methoxybenzzyl) ethanamine (25I-NBOMe); in vivo and ex vivo approaches. Neurochem Int 125:74-81. https://doi.org/10.1016/jneuint201 902007

Klein LM, Cozzi NV, Daley PF, Brandt SD, Halberstadt AL (2018) Receptor binding profiles and behavioral pharmacology of ring substituted N, N-diallyltryptamine analogs. Neuropharmacology 142:231-239. https://doi.org/10.1016/jneuropharm201802028

Koyama Y, Kayama Y (1993) Mutual interactions among cholinergic, noradrenergic and serotonergic neurons studied by ionophoresis of these transmitters in rat brainstem nuclei. Neuroscience 55:11171126. https://doi.org/10.1016/0306-4522(93)90325-a

Lawn W, Barrat M, Williams M, Horne A, Winstock A (2014) The NBOMe hallucinogenic drug series: pattern of use, characteristics of users and self-reported effects in a large international sample. J Psychopharmacol 28:780-788. https://doi.org/10.1177/02698 81114523866

Lebois EP, Thorn C, Edgerton JR, Popiolek M, Xi S (2018) Muscarinic receptor subtype distribution in the central nervous system and relevance to aging and Alzheimer disease. Neuropharmacology 136:362-373. https://doi.org/10.1016/jneuropharm201711018

Martin EI, Ressler K, Binder E, Nemeroff CB (2009) The neurobiology of anxiety disorders: brain imaging, genetics, and psychoneuroendocrinology. Psychiatr Clin N Am 32:549-575. https://doi.org/10. 1016/jpsc200905004

Martin-Ruiz R, Puig MV, Celada P, Shapiro DA, Roth BL, Mengod G, Artigas F (2001) Control of serotonergic function in medial prefrontal cortex by serotonin-2A receptors through a glutamatedependent mechanism. J Neurosci 21:9856-9866. https://doi.org/ 10.1523/JNEUROSCI21-24-098562001

Maura G, Giardi A, Raiteri M (1988) Release-regulating D-2 dopamine receptors are located on striatal glutamatergic nerve terminals. J Pharmacol Exp Ther 247:680-684

Meredith GE, Wouterlood FG (1990) Hippocampal and midline thalamic fibers and terminals in relation to the choline acetyltransferase-immunoreactive neurons in nucleus accumbens of the rat: a light and electron microscopic study. J Comp Neurol 296:204221. https://doi.org/10.1002/cne902960203

Miliano C, Marti M, Pintori N, Castelli MP, Tirri M, Arfe R, De Luca MA (2019) Neurochemical and behavioral profiling in male and female rats of the psychedelic agent 25I-NBOMe. Front Pharmacol 10:1406. https://doi.org/10.3389/fphar201901406
Miner LA, Backstrom JR, Sanders-Bush E, Sesack SR (2003) Ultrastructural localization of serotonin $2 \mathrm{~A}$ receptors in the middle layers of the rat prelimbic prefrontal cortex. Neuroscience 116:107-117. https://doi.org/10.1016/s0306-4522(02)00580-8

Mirjana C, Baviera M, Invernizzi RW, Balducci C (2004) The serotonin 5-HT2A receptors antagonist M100907 prevents impairment in attentional performance by NMDA receptor blockade in the rat prefrontal cortex. Neuropsychopharmacology 29:1637-1647. https://doi.org/10.1038/sjnpp1300479

Muschamp JW, Regina MJ, Hull EM, Winter JC, Rabin RA (2004) Lysergic acid diethylamide and [-]-2,5-dimethoxy-4-methylamphetamine increase extracellular glutamate in rat prefrontal cortex. Brain Res 1023:134-140. https://doi.org/10.1016/jbrainres2 00407044

Nagayama H, Lu JQ (1996) Circadian rhythm in the responsiveness of central 5-HT(2A) receptor to DOI in rats. Psychopharmacology 127:113-116. https://doi.org/10.1007/BF02805983

Nair SG, Gudelsky GA (2004) Activation of 5-HT2 receptors enhances the release of acetylcholine in the prefrontal cortex and hippocampus of the rat. Synapse 53:202-207. https://doi.org/10.1002/syn20 054

Nichols DE (2016) Psychedelics. Pharmacol Rev 68:264-355. https:// doi.org/10.1124/pr.115.011478

Noworyta-Sokolowska K, Kaminska K, Kreiner G, Rogoz Z, Gołembiowska K (2016) Neurotoxic effects of 5-MeO-DIPT: a psychoactive tryptamine derivative in rats. Neurotox Res 30:606619. https://doi.org/10.1007/s12640-016-9654-0

Noworyta-Sokolowska K, Kozub A, Jablonska J, Parkitna JR, Drozd R, Rygula R (2019) Sensitivity to negative and positive feedback as a stable and enduring behavioural trait in rats. Psychopharmacology 236:2389-2403. https://doi.org/10.1007/s00213-019-05333-w

Orzelska-Gorka J, Talarek S, Listos J, Kedzierska E, Fidecka S (2016) 1-NAME differential effects on diazepam and flunitrazepam responses of rats in the object recognition test. Pharmacol Rep 68:728-732. https://doi.org/10.1016/jpharep201603012

Paxinos G, Watson C (1998) The rat brain in stereotaxic coordinates, 7 th edn. Academic Press, Cambridge

Picciotto MR, Higley MJ, Mineur YS (2012) Acetylcholine as a neuromodulator: cholinergic signaling shapes nervous system function and behavior. Neuron 76:116-129. https://doi.org/10.1016/jneur on201208036

Pierce PA, Peroutka SJ (1989) Hallucinogenic drug interactions with neurotransmitter receptor binding sites in human cortex. Psychopharmacology 97:118-122. https://doi.org/10.1007/bf004 43425

Pisani A, Bernardi G, Ding J, Surmeier DJ (2007) Re-emergence of striatal cholinergic interneurons in movement disorders. Trends Neurosci 30:545-553. https://doi.org/10.1016/jtins200707008

Rickli A, Luethi D, Reinisch J, Buchy D, Hoener MC, Liechti ME (2015) Receptor interaction profiles of novel N-2-methoxybenzyl (NBOMe) derivatives of 2,5-dimethoxy-substituted phenethylamines (2C drugs). Neuropharmacology 99:546-553. https://doi. org/10.1016/jneuropharm201508034

Rogoz Z, Skuza G (2011) Anxiolytic-like effects of olanzapine risperidone and fluoxetine in the elevated plus-maze test in rats. Pharmacol Rep 63:1547-1552. https://doi.org/10.1016/s1734-1140(11) 70719-8

Rowley HL, Martin KF, Marsden CA (1995) Determination of in vivo amino acid neurotransmitters by high-performance liquid chromatography with o-phthalaldehydesulphite derivatization. J Neurosci Methods 57:93-99. https://doi.org/10.1016/0165-0270(94) 00132-z

Saito H, Matsumoto M, Togashi H, Yoshioka M (1996) Functional interaction between serotonin and other neuronal systems: focus on in vivo microdialysis studies. Jpn J Pharmacol 70:203-205. https://doi.org/10.1254/jjp70203 
Scruggs JL, Schmidt D, Deutch AY (2003) The hallucinogen 1-[2,5-dimethoxy-4-iodophenyl]-2-aminopropane (DOI) increases cortical extracellular glutamate levels in rats. Neurosci Lett 346:137-140. https://doi.org/10.1016/s0304-3940(03)00547-0

Seo J-Y, Hur K-H, Ko Y-H, Kim K, Lee B-R, Kim Y-J, Kim S-K, Kim S-E, Lee Y-S, Kim H-C, Lee S-Y, Jang C-G (2019) A novel designer drug, 25N-NBOMe, exhibits abuse potential via the dopaminergic systems in rodents. Brain Res Bull 152:19-26. https://doi.org/10.1016/jbrainresbull201907002

Singer HS, Minzer K (2003) Neurobiology of Tourette's syndrome: concepts of neuroanatomic localization and neurochemical abnormalities. Brain Dev 25:S70-S84. https://doi.org/10.1016/s03877604(03)90012-X

Straub C, Tritsch NX, Hagan NA, Gu C, Sabatini BL (2014) Multiphasic modulation of cholinergic interneurons by nigrostriatal afferents. J Neurosci 34:8557-8569. https://doi.org/10.1523/JNEUR OSCI0589-142014

UNODC Report (2016) World drug report United Nations publication. Sales No E16XI7 https://www.unodc.org/doc/wdr2016/ (accessed 5 Oct 2020)

Virk MS, Sagi Y, Medrihan L, Leung J, Kaplitt MG, Greengard P (2016) Opposing roles for serotonin in cholinergic neurons of the ventral and dorsal striatum. PNAS 113:734-739. https://doi.org/ $10.1073 /$ pnas 1524183113

Ward RP, Dorsa DM (1996) Colocalization of serotonin receptor subtypes 5-HT2A 5-HT2C and 5-HT6 with neuropeptides in rat striatum. J Comp Neurol 370:405-414. https://doi.org/10. 1002/(SICI)1096-9861(19960701)370:3\%3c405::AID-CNE10\% $3 \mathrm{e} 30 \mathrm{CO} ; 2-\mathrm{R}$

Weber ET, Andrade R (2010) Htr2a gene and 5-HT2A receptor expression in the cerebral cortex studied using genetically modified mice. Front Neurosci 4:36. https://doi.org/10.3389/fnins 201000036

Wedzony K, Limberger N, Spath L, Wichman T, Starke K (1988) Acetylcholine release in rat nucleus accumbens is regulated through dopamine $\mathrm{D}_{2}$-receptor. Naunyn- Schmiedeberg's Arch Pharmacol 338:250-255. https://doi.org/10.1007/BF00173396

Willins DL, Deutch AY, Roth BL (1997) Serotonin 5-HT2A receptors are expressed on pyramidal cells and interneurons in the rat cortex. Synapse 27:79-82. https://doi.org/10.1002/(SICI)10982396(199709)27:1\%3c79::AID-SYN8\%3e30CO;2-A

Zhang G, Stackman RW Jr (2015) The role of serotonin 5-HT2A receptors in memory and cognition. Front Pharmacol 6:225. https://doi. org/10.3389/fphar201500225

Zhang G, Asgeirsdottir HN, Cohen SJ, Munchow AH, Barrera MP, Stackman RW Jr (2013) Stimulation of serotonin 2A receptors facilitates consolidation and extinction of fear memory in C57BL/6J mice. Neuropharmacology 64:403-413. https://doi.org/ 10.1016/jneuropharm201206007

Publisher's note Springer Nature remains neutral with regard to jurisdictional claims in published maps and institutional affiliations. 